\title{
Adipose tissue stem cells in regenerative medicine
}

\section{Vanesa Verónica Miana and Elio A Prieto González}

Centre for Advanced Studies in Humanities and Health Sciences, Interamerican Open University, Buenos Aires, Argentina

Correspondence to: Elio A Prieto González. Email: Elio.Prietto@vaneduc.edu.ar

\begin{abstract}
Adipose tissue-derived stem cells (ADSCs) are mesenchymal cells with the capacity for self-renewal and multipotential differentiation. This multipotentiality allows them to become adipocytes, chondrocytes, myocytes, osteoblasts and neurocytes among other cell lineages. Stem cells and, in particular, adipose tissue-derived cells, play a key role in reconstructive or tissue engineering medicine as they have already proven effective in developing new treatments. The purpose of this work is to review the applications of ADSCs in various areas of regenerative medicine, as well as some of the risks associated with treatment with ADSCs in neoplastic disease.
\end{abstract}

Keywords: adipose tissue stem cells, reconstructive surgery, secretome, stem cell treatment, cancer

Published: 28/03/2018

Received: 14/08/2017

ecancer 2018, 12:822 https://doi.org/10.3332/ecancer.2018.822

Copyright: (c) the authors; licensee ecancermedicalscience. This is an Open Access article distributed under the terms of the Creative Commons Attribution License (http://creativecommons.org/licenses/by/3.0), which permits unrestricted use, distribution, and reproduction in any medium, provided the original work is properly cited. 


\section{Introduction}

Stem cells can be classified by their origin as: (a) embryonic; (b) fetal; (c) adult and (d) induced pluripotent. The classification can be simplified as embryonic and adult mesenchymal [1].

Human embryonic stem cells (ES cells) are derived from the inner layer of the blastocyst and, due to their pluripotency, are used in tissue engineering and regenerative medicine. Human fetal mesenchymal stem cells (hfMSCs) can be harvested from stem cells present in the amniotic fluid or the umbilical cord. They are multipotent, but like the embryonic cells they present difficulties in harvesting them due to their limited availability and also due to ethical issues. The induced pluripotent stem cells (iPSCs) do not present major limitations in terms of harvesting, and the greatest difficulty in terms of their clinical use is related to the induction procedures in the laboratory to differentiate them into specific cells needed for the treatment of certain diseases [2]. For this reason, adult stem cells are the most promising for use in clinical practice and in research on the basic aspects of this cellular compartment.

Adipose tissue-derived stem cells (ADSCs) are mesenchymal cells, which have a capacity for self-renewal and which can also be differentiated into adipocytes, chondrocytes, myocytes, osteoblasts and neurocytes among other cell lineages [3], which has resulted in them being used in clinical trials for the treatment of conditions such as diabetes mellitus, liver disease, corneal lesions, articular and cutaneous lesions, among others [4-10]. In addition, stem cells and, in particular, adipose tissue-derived cells, play a key role in reconstructive or tissue engineering medicine as they can be used to develop new treatments. [11].

Among the advantages of ADSCs, the greater ease of access and harvesting by means such as subcutaneous lipoaspiration, a much less painful procedure than harvesting bone marrow stem cells, and their use, is less associated with ethical controversies because they are harvested from autologous fat, unlike ES cells [12].

Adipose tissue has been one of the most studied tissues in the last decade due to its endocrine activity which is manifested in the release of adipocytokines, cytokines, transcriptional and growth factors, which forms a secretome [11, 13, 14]. Adipose tissue is no longer only considered an energy reservoir, thermal insulator or mechanical buffer, but its participation in a complex network of interactions with the endocrine, nervous and cardiovascular systems has been highlighted. It is a tissue that originates in the mesoderm and is formed by adipocytes and a fraction of stromal cells that include vascular smooth muscle cells, endothelial cells, fibroblasts, monocytes, macrophages, pre-adipocyte lymphocytes and ADSCs. ADSCs may undergo differentiation to mesodermal or trans-mesodermal lineages and give rise to cells that are naturally of ectodermal origin [1].

The procedure based on the separation of the vascular stroma contained in adipose tissue has allowed access to stem cells without resorting to embryonic tissue, facilitating its use in regenerative medicine [1, 12]. The (CD34 +) ADSCs are those that can differentiate and form nonhematopoietic colonies, in turn they form a compartment in which various subpopulations are identified: pro endothelial (CD146 + / CD31 + / CD34 +); pericytes (CD146 + / CD31- / CD34-), a transient subpopulation (CD146 + / CD31- / CD34 +); and stromal cells that show a greater potential to form adipocytes (CD146- / CD31- / CD34 +) [15].

In recent years, it has been demonstrated that by using specific inducers in the laboratory, these adipose-derived stem cells (ADSCs) have the ability to differentiate into the cellular line needed $[12,16]$.

The purpose of this project is to review the applications of adipose tissue stem cells in different conditions including cancer, as well as to highlight some problems associated with the use of these cells in oncology and especially in post-surgical tissue reconstruction.

\section{Methods}

This review project was carried out through the evaluation of biomedical journals indexed in MEDLINE, PubMed, Scielo, SIIC and Redalic using search terms such as 'tissue engineering and oncology', 'regenerative medicine', 'biomaterials', 'adipose tissue' and 'stem cells'.

The review included articles in English and Spanish and publications from the last 5 years, as well as other less recent ones that, due to their importance or uniqueness, seemed relevant to us. 


\section{Adipose tissue stem cells in regenerative medicine}

\section{Characteristics of stem cell harvesting}

Adipose tissue is a specific variety of connective tissue; composed of a group of cells called adipocytes, specialised in storing fats. The adipose tissue consists of the joining, through reticular fibres, of the adipocytes forming lobes, between which run numerous blood vessels.

Adipose tissue adult stem cells, termed stem cells or mesenchymal stem cells (MSCs), can be harvested through surgery and direct excision, liposuction in the trunk and extremities as well as the Coleman technique for fat tissue transplantation and remodelling. This technique has shown a higher yield of viable adipocytes than conventional liposuction $[1,17,18]$. In liposuction, the unwanted fat of a part of the body is removed by aspiration and injected in the areas where increased volume is required or to achieve a cosmetic improvement. [19, 20]. The isolation of ADSCs is carried out from the lipoaspirated material where the cells of the stromal vascular fraction (SVF) can be found; from this fraction, different cell types can be isolated after washing, enzymatic digestion and centrifugation of the samples [16, 21, 22]. The cell types found in SVF include: preadipocytes, fibroblasts, adult mesenchymal stem cells, monocytes, macrophages, lymphocytes as well as pericytes related to angiogenesis. [23-25].

\section{Harvesting cell lines}

Maintaining cultures of mesenchymal cell lines allows a greater quantity of pluripotent stem cells (PSC) to be harvested. However, at this time there is much controversy about the most efficient methods of cell derivation and reprogramming and which culture conditions allow them to maintain their undifferentiated state in an unlimited way. Cultures that could retain a stable phenotype could be induced to differentiate into a specific cell lineage/tissue in a specific and reproducible manner at the desired time [12, 26, 27].

The main challenge for the application of these cells in future cell replacement therapies is to be able to control their differentiation in specific tissues. In this sense, there are a multitude of cultivation methods, reprogramming strategies, genetic manipulation, epigenetic modulation as well as organisation in three-dimensional matrices and directing stem cells to the areas where they may be needed [12, 28, 29].

The feeder cells that have been most used in the cultivation of human PSCs are mouse embryonic fibroblasts (MEFs) [30]. These cells secrete nutrients into the medium and form a single layer, acting as a cellular support on which the PSCs are placed. Recently, the use of feeder layers of nonhuman origin has begun to be ruled out as well as the use of a medium conditioned by feeder cells due to the suspicion that they can be carriers of murine viruses [31].

The feeder layers that have replaced them are made up of human embryonic fibroblasts and the extra cellular medium that these have conditioned. There is a remarkable input of cytokines, growth factors among others, that enrich or condition the cultivation medium with elements from the same species. The co-cultivation of stem cells and human feeder cells is safer and is a model which is closer to natural conditions. Another approach to the problem of guaranteeing the suitability of the cultures is the development of serum-free and xenobiotic-free media [31].

Tissue regeneration using stem cells has incorporated three-dimensional matrices constructed by different biomaterials to provide a microenvironment closer to that of the natural histoarchitecture. Matrices along with growth factors, such as bone morphogenetic protein 2 and culture expanded adipose stem cells, are used in tissue reconstruction, for example, after cancer surgery [32].

Biomaterials are important in the culture of SCs as they are three-dimensional polymeric structures used to achieve an organisation of cell growth, closer to that of tissues [33-35]. Among the materials used to assemble the three-dimensional biomatrices so that the stem cells can embed, we can include silica, collagen and hyaluronic acid that interacts with the SCs through integrin-like proteins. The biomatrices formed by collagen increase the range of differentiation possibilities in different cell lineages such as cartilage, bone, skin and lung, while others formed by polysaccharides that are not found in the extracellular matrix limit their possibilities of differentiation [34]. The size of the particles or the density of the networks that are developed by various biomaterials such as silica that influences the growth and differentiation potential of ADSCs. It has been proven that kinase systems are involved in transducing signals generated by cell contact with the biomatrices. The mitogen-activated kinases seem to be the base of the proliferative effects of such culture conditions and may be related to the acquisition of malignant phenotype of ADSCs in experimental models or in reconstructive surgery [36], as we will see later. 


\section{Cultivation and genomic alterations of cultured stem cells}

The appearance of mutations in genes controlling the integrity of DNA promotes genomic instability, which leads to diversification into cellular subpopulations that in turn can accumulate further mutations and give rise to cell genotypes that can express the tumour phenotype [37].

The cells transformed through cultivation mimic the tumour phenotype in vivo. It is then necessary to evaluate the genetic stability of cultures that have therapeutic purposes.

Maitra et al [38] studied genomic stability in human ESM cell lines and compared the frequency of mutations between the early and late passages (after the eighth or ninth passage). In late passages, an increase in the number of genomic alterations was observed that coincided with some of those that appear in malignant tumours, including aneuploidies, mutations in mitochondrial DNA and alterations in methylation. The fact that stem cell lines develop genetic and epigenetic alterations in vitro implies the need to use them before derivations that could increase their oncogenic potential produced in cultivation [37].

According to Gimble et al [39], five criteria must be followed for the use of these cells for medical purposes: (a) Presence of cells in abundance. (b) Harvesting through minimally invasive procedures. (c) Regulation of the differentiation of cell lineages. (d) Possibility of their use as autograft. (e) They must be manipulable within the rules of professional practice.

\section{ADSCs in experimental and human studies}

Handling in the laboratory and their transfer and inoculation in the operating room must be done in compliance with biosafety regulations and respecting regulations concerning the ethics of therapeutic procedures.

The animal model test records are abundant, for that reason some are selected, by way of illustration, in a growing field where one cannot claim to be exhaustive.

ADSCs have been used in experiments in a model of osteoporosis in rats in which differentiated stem cells were implanted to regenerate bone tissue. Over a period of 2 years, regeneration of affected bone tissue was achieved [40-42, 45-47].

Bacou et al [43] documented a study on rats in which cells differentiated from ADSCs were injected into the injured tibialis anterior muscle in order to evaluate whether muscle tissue regeneration occurred; after 60 days in the treated group, the cross-section of muscle and maximal contraction force increased compared to the untreated control group. Meanwhile, another author reported the production of dystrophin in mice, in a model of Duchenne muscular dystrophy, when ADSCs were transplanted [44].

In a model of autoimmune thyroiditis in $\mathrm{C} 57 \mathrm{~B} / 6$ mice, the therapeutic effects of ADSC transplants were studied from mice of the same line (syngenic) and BALB/c (allogenic) mice. In both cases, with both allogeneic and syngeneic ADSCs, there was a decrease in the amount of antithyroglobulin autoantibodies as well as inflammatory response and the balance between Th1/Th2 was restored [48].

In a model of rheumatoid arthritis in rats, the syngenic and allogenic transplantation of mouse or human ADSCs resulted in less cartilage damage and decreased antibodies against mouse collagen II, as well as interleukin 6 in the treated groups [49]. Research on murine models has been published in which repopulation of the pancreas was observed with cell aggregates similar to the islets of Langerhans, which were formed from ADSCs and are capable of secreting insulin [50, 51].

\section{In vivo and clinical trials in the cardiac muscle}

Attempts were made to repopulate areas of the cardiac muscle after a heart attack in both animal models and humans. Tests were conducted by injecting stem cells directly into the site of the post-infarction lesion with the purpose of restoring the thickness and elasticity of the walls, alterations that often result in ventricular failure. However, the results have not been satisfactory. Apparently, the absence of a syncytium in which the transplanted cells can be fixed and proliferate is one of the causes of these failures, and so several biomatrices have been introduced, such as those based on peptide nanofibers capable of self-assembly in three-dimensional networks and with better results in retention and proliferation of the transplanted cells [52]. 
ADSCs have greater capacity for differentiation into epithelial cells and promotion of angiogenesis; it is known that hypoxia favours the secretion of growth factors that contribute to the proliferation of myocardiocytes and the reduction of infarcted areas. It has also been observed that fat cells originating from epicardial fat are phenotypically closer to myocardiocytes and consequently easier to differentiate in such cardiac cells than in those harvested in other regions, such as omental fat. The paracrine activity of these cells' secretome also favours differentiation into myocardiocytes [53].

Other authors report that ADSCs permeabilised and treated with factors secreted by myocardiocytes have increased their proliferative capacity at the transplant site and secreted cardiac cell markers, such as troponin, sarcomeric alpha actinin and desmin [54, 59, 82].

The genetic manipulation of ADSCs is a pathway that is being explored in experimental models involving research and treatment of different liver or heart conditions [55-58]. An example of this approach in which transgenesis and ADSC therapy cross is the study in which they have been transduced with the haem oxygenase 1 gene, the product of which decreased oxidative damage and apoptosis of myocardiocytes. In a model of myocardial infarction in rabbits, modified ADSCs were transplanted in order to over-express the enzyme while a control group was treated with unmodified cells. When they were evaluated 4 weeks after the treatment, those that had received modified cells expressed a greater quantity of markers such as connexin 43 and tyrosine hydroxylase as well as greater differentiation towards myocardiocytes, increase in angiogenesis, a decrease in post-infarction scars and a growth of sympathetic nerves [59].

\section{Clinical trials in bone tissue}

In patients with bone deficiencies in the jaws, who were treated with ADSCs in addition to a bone matrix and autologous fibrin, when the grafts were checked in a tomography performed 90 days after the procedure, bone growth was checked in the deficit areas [60,61].

An example of the application of ADSC transplants in reconstructive medicine has been the restorative treatment of the cranial vault of a 7-year-old girl after a serious injury, with bone resorption in which a decompressive craniotomy had to be performed, leaving a cranial defect of $120 \mathrm{~cm}^{2}$ as a sequela. The patient was treated with $15 \mathrm{ml}$ iliac cancellous bone supplemented with $10 \mathrm{ml}$ of ADSCs that were harvested and isolated during the surgical procedure. A tissue adhesive consisting of autologous fibrin glue and resorbable mesh was used to increase graft stability. Monitoring with posterior tomography showed a significant reossification at 3 months which made it possible to remove the protection that had been inserted the previous year at the time of the injury. [61]

ADSCs have the ability to differentiate into the cell line that is needed for the regenerative treatment of different conditions such as coronary disease, osteoporosis, bone regeneration of the jaw and the vestibular table, in amyotrophic lateral sclerosis, osteogenesis imperfecta, Crohn's disease (closure of entire cutaneous fistulas), alopecia, graft versus host disease and diabetes mellitus [62-64].

This means that the field of experimental research on the application of ADSCs is expanding and parallel clinical trials are developing, which leads to an experimental and clinical complementation bringing cell therapy closer to the standards of mainstream medical practice. On this website, clinical trials with ADSCs that are currently in progress may be consulted (https://clinicaltrials.gov/adipose derived stem cells).

\section{ADSCs in cancer therapy}

In recent years, concerning the use of these cells for the treatment of different cancers, evidence indicates that these cells may have a protumourigenic or anti-tumourigenic role, depending on different factors such as the types of ADSCs, their origin, the cell line of the cancer studied, the interactions between ADSCs and the cells of the host immune system [65].

In one way or another, the effects are related to a set of biological actions of the SC whose determinants are not yet well understood. SCs can promote the expression of growth factors as well as the development of tumour stem cells. The pro-tumourigenicity of the SC is explained by the formation of blood vessels;, and also, by the increased survival of tumour stem cells, by decreasing body's immune response to the tumour and contributing to the formation of metastases. The origin of SCs is a factor that conditions the response to different types of tumours, which further complicates the picture [66-68]. 
Regarding antitumour actions, there are reports in experimental models that include melanomas, pancreatic cancer and prostate cancer about which stem cells of different origins, such as bone marrow and adipose tissue, were able to cause tumour size reduction by mechanisms that included the inhibition of angiogenesis, apoptosis and interference with cell proliferation, which is the mechanism used to explain the effect on prostate cancer in nude mice treated with ADSCs [65].

Other approaches to use ADSCs in Oncology include the encapsulation of ADSCs to protect them and guarantee that they can serve as vectors for antineoplastic drugs taking advantage of the tropism of migration towards the primary tumour or its metastasis [68]. The use of genetically-modified SCs to carry tumouricidal genes can serve as a 'magic bullet' against neoplastic cells. In experimental murine models, positive results have been obtained in gliomas, Kaposi's sarcoma, melanoma or lung cancer. Interleukins and interferons are among the factors that can be carried by SCs to the tumour site. It is also worth mentioning that the suicide gene therapy is based on sending inactive prodrugs together with cells modified to express transgenic enzymes that can modify the precursors, making them toxic in the tumour site [69].

\section{ADSC therapy and oncogenic risk}

Within the tumour structure are the parenchyma and the stroma involving the vessels and the connective tissue. The stroma is of great importance in the nutrition of tumour cells [68, 70]. The stroma participates in the regulation of growth and spread of a tumour through interaction with parenchymal cells. Among the cells associated with the tumour are myofibroblasts that have a role in metastasis by stimulating angiogenesis via the stromal factor-1 (SDF-1) and secretion of metalloproteases that help to reshape the extracellular matrix [71, 72].

A potential source of stromal cells is multipotent mesenchymal stem cells $[25,73,74]$. In addition to their recognised characteristics of multipotentiality and self-renewal, stem cells show tropism of migration towards tumour cells, which is an advantage for treatment although at the same time it increases the possibility of recruitment towards the tumour phenotype as a consequence of paracrine stimuli [75].

The mechanisms that can explain the role of MSCs in tumour progression include the decrease in the immunological reactivity of tumour cells which leads to a greater spread of cancer. The molecules secreted by the neoplastic cells are the carriers of the communication that results in the modification of the behaviour of the stromal cells, their recruitment and further modulation of the tumour phenotype [76]. In addition to the secretion pathways that characterise paracrine stimulation, there are exosomes that are nanoscale vessels originating in intracellular multivesicular bodies and that have been found in reticulocytes, enterocytes, tumour cells and SCs among others. These vessels contain proteins that are related to the presentation of antigens of the major histocompatibility complex, as well as to signal transduction, migration and cell adhesion. They also contain heat shock proteins and MFG-E8 or lactaderin, which is related to the phagocytosis of apoptotic cells. It is striking that they include mRNA and microRNA that are functional in the target cells [77-79].

Exosomes are a paracrine pathway that involves the massive transport of proteins and the induction of pleiotropic cellular responses, participate in the crosstalk between SCs and other cell types and function in pro-tumourigenic recruitment and activation of remaining cancer cells, after cancer therapy, can exert on tissues carrying mesenchymal stem cells. This becomes important when an autograft or allograft of adipose tissue is performed in breast reconstruction following cancer surgery [11, 80].

In cancer patients with a recommendation for breast reconstruction, the surgical option with transverse rectus abdominis muscle (TRAM) flap is one of the most used for breast reconstruction after performing a radical mastectomy. The use of stem cells in the reconstruction process reduces the appearance of fat necrosis around the flap. Stem cells improve the viability of the TRAM flap and significantly reduce peripheral tissue necrosis [81, 82].

Despite fears about the risks of malignant transformation that may be associated with the use of autologous ADSC, very low frequencies of loco-regional tumour recurrences have been reported in post-surgery breast cancer reconstruction. [83, 84] This contradicts the experimental results in which the oncogenic potential of the ADSC secretoma is demonstrated, and also, expresses the great complexity and heterogeneity of the factors that can promote or antagonise the malignant transformation when ADSC is transplanted [85, 86]. 


\section{Effect of ADSC on scarring}

There are several stages of scarring that, from the biochemical point of view, are characterised by the release of different growth factors. In the acute phase, transforming growth factor beta (TGF $\beta$ ), granulocyte colony stimulating factor, platelet derived growth factor (PDGF) and inflammatory cytokines are identified. In the cell proliferation phase in which the granulation tissue is formed, the epidermal growth factor (EGF), the tumour necrosis factor, the vascular endothelial growth factor, the growth of keratinocytes (KGF), insulin growth factor, nervous growth factor, as well as inflammatory interleukins. In the final or remodelling stage, factors that induce epithelialisation are produced, such as KGF, TGF $\beta$, PDGF, EGF and hepatocyte growth factor [87, 88].

It is worth noting that a large part of the therapeutic effect of ADSC can be explained by the endocrine activity of adipose tissue. An example of which is the fact that, by decreasing blood flow, as in the case of flap reconstruction and hypoxia, ADSCs increase the production of fibroblast growth factor while increasing the secretion of angiogenic factors that contribute to revascularisation. Evidence abounds that the factors secreted by stem cells have therapeutic effects that are expressed in tissue regeneration and are also effective in other aspects, such as in the reduction in neuropathic pain in diabetes [86-89, 90-93].

In a model of excisional scars in BALB/c mice, the factors secreted by ADSCs were able to increase the speed of healing and attenuate the deposit of collagen. In the same study, it is reported that the incubation of fibroblasts and tissue from hypertrophic scars, with a medium conditioned by ADSCs, decreased the expression of alpha actin and of collagens I and II; whose fibres were finer and more organised than those of untreated cultures. The meaning of these results, the reduction of cutaneous fibrosis that generates deforming scars, cannot be minimised [94].

\section{Other research avenues involving stem cell therapy}

The information reviewed here allows us to affirm that there is an increase in the possibilities of ADSC use in conditions in which, for different reasons, there are injuries with total or partial tissue loss. In this sense, the projections include traumas with avulsion wounds, fractures in which bone mass is destroyed and burns, which areamong others [95, 96].

In some neurodegenerative diseases, the capacity of genetically modified ADSC is explored in order to counteract the cytotoxic effects of substances generated in patient's cells [97].

In autoimmune conditions, the ability to interfere with the alterations of humoral and cellular immunity provides an avenue of research that is already gathering some promising results in the medium term [98, 99].

Research into the possibilities of stem cells intersects with other areas such as transgenesis and gene editing. In this sense, not only it is intended to induce the differentiation of stem cells in specific lineages according to therapeutic needs but also stem cells can be modified at the genetic level, so that cell therapy also becomes a gene therapy which can be used to correct defects such as congenital metabolism errors resulting in enzymatic deficits or structural proteins. Stem cells could function as vectors for the transduction of corrective genes [100-102]. The epigenetic modulation of SCs before and after they have been introduced into the recipient is another avenue that should be explored, especially in those conditions in which errors that require regulation of the activity of the transplanted cells must be corrected [103, 104].

Regenerative medicine and, within it, reconstructive surgery where cellular and molecular biology intersect, with the proper surgical restorative procedures, will contribute to shape the medicine of the near future. Although not ready in the near future, the restructuring or regeneration of parts of organs or whole organs has a solid base in recent stem cell therapy results.

\section{Conclusions}

ADSCs are an accessible and more flexible alternative for treating conditions that require tissue regeneration. Their therapeutic efficacy is founded on the applications based on these cells not only in experimental models in animals but also in an increasing number of human trials. 
Conditions that can be treated with ADSCs range from traumatic injuries, through to neurodegenerative and endocrine metabolic disorders, and postsurgical reconstructions.

In relation to antineoplastic treatment, the paracrine and endocrine stimuli mediated by the secretomas of the ADSC may be beneficial, but may also promote tumour progression.

The development of the use of ADSCs in the treatment of highly prevalent conditions involves not only cell transplantation, but intersects with genetic manipulation, epigenetic modulation and the effect of secretomas correcting pathophysiological alterations.

\section{Acknowledgments}

To Dr Marina Bramajo, for her selfless collaboration.

\section{References}

1. Brown JC, Shang H, and Li Y, et al (2017) Isolation of adipose-derived stromal vascular fraction cells using a novel point-of-care device: cell characterization and review of the literature Tissue Eng Part C Methods 23(3) 125-135 https://doi.org/10.1089/ten. tec.2016.0377 PMID: 28177263

2. Charvet $\mathrm{HJ}$, Orbay $\mathrm{H}$, and Harrison L, et al (2016) In vitro effects of adipose-derived stem cells on breast cancer cells harvested from the same patient Ann Plast Surg 76(Suppl 3) S241-S245 https://doi.org/10.1097/SAP.0000000000000802 PMID: 27070671

3. Thomson JA, Itskovitz-eldor J, and Shapiro SS, et al (2011) Embryonic stem cell lines derived from human blastocysts Science 5391(282) 1145-1147

4. Gimeno ML, Hyon SH, and Argibay PF (2011) Terapia celular para el tratamiento de la diabetes: más allá de las células madre Medicina 3(71) 267-273

5. Do Amaral RJFC, Almeida HV, and Kelly DJ, et al (2017) Infrapatellar fat pad stem cells: from developmental biology to cell therapy Stem Cells Int 6843727 http://doi.org/10.1155/2017/6843727 PMID: 29018484 PMCID: $\underline{506137}$ Date accessed: 10/02/2018

6. Hanson C, Arnarsson A, and Hardarson T, et al (2017) Transplanting embryonic stem cells onto damaged human corneal endothelium World J Stem Cells 9(8) 127-132 https://doi.org/10.4252/wjsc.v9.i8.127 PMID: 28928909 PMCID: 5583531 Date accessed: 06/11/2017

7. Jung WY, Kang JH, and Kim KG, et al (2015) Human adipose-derived stem cells attenuate inflammatory bowel disease in IL-10 knockout mice Tissue Cell 47(1) 86-93 https://doi.org/10.1016/j.tice.2014.12.001

8. Liu WH, Song FQ, and Ren LN, et al (2015) The multiple functional roles of mesenchymal stem cells in participating in treating liver diseases J Cell Mol Med 19(3) 511-520 https://doi.org/10.1111/jcmm.12482 PMCID: $\underline{369809}$

9. Stepien A, Dabrowska NL, and Maciagowska M, et al (2016) Clinical application of autologous adipose stem cells in patients with multiple sclerosis: preliminary results Mediators Inflamm 53021205 https://doi.org/10.1155/2016/5302120

10. Hur W, Lee HY, and Min HS, et al (2017) Regeneration of full-thickness skin defects by differentiated adipose-derived stem cells into fibroblast-like cells by fibroblast-conditioned medium Stem Cell Res Ther 8(1) 92 https://doi.org/10.1186/s13287-0170520-7 PMID: 28427476 PMCID: 5399413

11. Zimmerlin L, Park TS, and Zambidis ET, et al (2013) Mesenchymal stem cell secretome and regenerative therapy after cancer Biochimie 95 2235-2245 https://doi.org/10.1016/j.biochi.2013.05.010 PMID: 23747841 PMCID: $\underline{3825748}$ 
12. Gimble J, Katz A, and Bunnell B (2009) Adipose-derived stem cells for regenerative medicine Circ Res $1001249-1260$ [http://circres. ahajournals.org] https://doi.org/10.1161/01.RES.0000265074.83288.09 Date accessed: 06/11/2017

13. Kim EY, Kim WK, and Oh KJ, et al (2015) Recent advances in proteomic studies of adipose tissues and adipocytes Int J Mol Sci 16(3) 4581-4599 https://doi.org/10.3390/ijms16034581 PMID: 25734986 PMCID: 4394436

14. Coelho M, Oliveira T, and Fernandez R (2013) Biochemistry of adipose tissue: an endocrine organ Arch Med Sci 9(2) 191-200 https://doi.org/10.5114/aoms.2013.33181 PMID: 23671428 PMCID: $\underline{3648822}$

15. Zimmerlin L, Donnenberg VS, and Rubin JP, et al (2013) Mesenchymal markers on human adipose stem/progenitor cells Cytometry A 83(1) 134-140 https://doi.org/10.1002/cyto.a.22227

16. Lindroos B, Suuronen R, and Miettinen S (2011) The potential of adipose stem cells in regenerative medicine Stem Cell Rev 7(2) 269-291 https://doi.org/10.1007/s12015-010-9193-7

17. Pu LL, Coleman SR, and Cui X, et al (2008) Autologous fat grafts harvested and refined by the Coleman technique: a comparative study Plast Reconstr Surg 122(3) 932-937 https://doi.org/10.1097/PRS.0b013e3181811ffo PMID: 18766062

18. Iyyanki T, Hubenak J, and Liu J, et al (2015) Harvesting technique affects adipose-derived stem cell yield Aesthet Surg J 35(4) 467-476 https://doi.org/10.1093/asj/sju055 PMID: 25791999 PMCID: 4532626

19. Planas Ribo J and Coronel Gagliardi R (2011) Obtención y criopreservación de células madre de tejido adiposo mediante liposucción Cir plástica Iberoamericana 37(4) 319-324 https://doi.org/10.4321/S0376-78922011000400002

20. Ávila Portillo LM, Franco Ruiz DJ, and Ávila García JP, et al (2015) Comparison of the viability and growth in stem cell culture obtained from adipose tissue (ADAS) pre and post freeze Nova 13(24) 27-38 https://doi.org/10.22490/24629448.1714

21. Almeida KA, Campa A, and Alonso-Vale MIC, et al (2008) Fracción vascular estromal de tejido adiposo: cómo obtener células madre y su rendimiento de acuerdo a la topografía de las áreas donantes: estudio preliminar Cir plást Iberolatinoam 34(1) 71-77 https://doi.org/10.4321/S0376-78922008000100009

22. Dos-Anjos S, Mercader J, and Katz, AJ, et al (2013) Nuevo dispositivo para el aislamiento de la fracción estromal vascular a partir de lipoaspirados humanos: método de obtención y análisis de calidad cellular Cir plást lberolatinoam 39(supp1) 39-43 https://doi.org/10.4321/S0376-78922013000500011

23. Koh YJ, Koh BI, and Kim H, et al (2011) Stromal vascular fraction from adipose tissue forms profound vascular network through the dynamic reassembly of blood endothelial cells Arterioscler Thromb Vasc Bio/ 31(5) 1141-1150 https://doi.org/10.1161/ ATVBAHA.110.218206 PMID: 21393582

24. Tang QQ and Lane MD (2012) Adipogenesis: from stem cell to adipocyte Annu Rev Biochem 81 715-36 https://doi.org/10.1146/ annurev-biochem-052110-115718 PMID: 22463691

25. Bourin P, Bunnell BA, and Casteilla L, et al (2013) Stromal cells from the adipose tissue-derived stromal vascular fraction and culture expanded adipose tissue-derived stromal/stemcells: a joint statement of the International Federation for Adipose Therapeutics and Science (IFATS) and the International Society for Cellular Therapy (ISCT) Cytotherapy (6) 641-8 https://doi. org/10.1016/j.jcyt.2013.02.006 PMID: 23570660 PMCID: $\underline{3979435}$

26. Pineda MC and Lodoño PC (2009) Obtención de células madre de tejido adiposo y su potencial de diferenciación ontogénico Revista de Ingeniería Biomédica 3(5) 58-65

27. Meruane M and Rojas M (2010) Células troncales derivadas del tejido adiposo Int J Morpho/ 28(3) 879-889 https://doi.org/10.4067/ $\underline{\text { S0717-95022010000300035 }}$

28. Frese L, Dijkman PE, and Hoerstrup SP (2016) Adipose tissue-derived stem cells in regenerative medicine Transfus Med Hemother 43(4) 268-274 https://doi.org/10.1159/000448180 PMID: 27721702 PMCID: $\underline{5040903}$ 
29. Ghiasi M, Kalhor N, and Tabatabaei Qomi R, et al (2016) The effects of synthetic and natural scaffolds on viability and proliferation of adipose-derived stem cells Front Life Sci 9(1) 32-43 https://doi.org/10.1080/21553769.2015.10774777

30. Lapillonne H, Kobari L, and Mazurier C, et al (2010) Blood cell generation from human induced pluripotent stem cells: perspectives for transfusion medicine Haematologica 95(10) 1651-1659 https://doi.org/10.3324/haematol.2010.023556 PMID: 20494935 PMCID: 2948089

31. Menéndez Buján P and y cols (2010) Uso de un medio de cultivo condicionado por células madre mesenquimales para la diferenciación de células madre pluripotentes humanas W02011124741 A1 Disponible en [http://www.google.com/patents/ WO2011124741A1?cl=es]

32. Sándor GK, Tuovinen VJ, and Wolff J, et al (2013) Adipose stem cell tissue-engineered construct used to treat large anterior mandibular defect: a case report and review of the clinical application of good manufacturing practice-level adipose stem cells for bone regeneration J Oral and Maxillofac Surg 71(5) 938-950 https://doi.org/10.1016/j.joms.2012.11.014

33. Burdick JA and Vunjak-Novakovic G (2009) Engineered microenvironments for controlled stem cell differentiation Tissue Engg A 2(15) 205-219 https://doi.org/10.1089/ten.tea.2008.0131

34. Wan LQ, Kang SM, and Eng G, et al (2010) Geometric control of human stem cell morphology and differentiation Integr Biol (Camb) 2(7-8) 346-353 https://doi.org/10.1039/c0ib00016g

35. Chen G, Lv Y, and Guo P, et al (2014) Matrix mechanics and fluid shear stress control stem cells fate in three dimensional microenvironment Curr Stem Cell Res Ther 8(4) 313-323 https://doi.org/10.2174/1574888X11308040007

36. Kim KJ, Joe YA, and Kim MK, et al (2015) Silica nanoparticles increase human adipose tissue-derived stem cell proliferation through ERK1/2 activation Int J Nanomedicine 10 2261-2272 https://doi.org/10.2147/IJN.S71925 PMID: 25848249 PMCID: $\underline{4378289}$

37. Negrini S, Gorgoulis VG, and Halazonetis TD (2010) Genomic instability--an evolving hallmark of cancer Nat Rev Mol Cell Biol 11(3) 220-228 https://doi.org/10.1038/nrm2858 PMID: 20177397

38. Maitra A, Arking DE, and Shivapurkar N, et al (2005) Genomic alterations in cultured human embryonic stem cells Nature Genetics 37 1099-1103 https://doi.org/10.1038/ng1631 PMID: 16142235

39. Gimble JM, Katz AJ, and Bunnell BA (2007) Adipose-derived stem cells for regenerative medicine Circ Res 100(9) 1249-1260 https://doi.org/10.1161/01.RES.0000265074.83288.09 PMID: $\underline{17495232}$ PMCID: $\underline{5679280}$

40. Cui L, Liu B, and Liu G, et al (2007) Repair of cranial bone defects with adipose derived stem cells and coral scaffold in a canine model Biomaterials 28 5477-5486 https://doi.org/10.1016/j.biomaterials.2007.08.042 PMID: 17888508

41. Mehrabani D, Hassanshahi MA, and Tamadon A, et al (2015) Adipose tissue-derived mesenchymal stem cells repair germinal cells of seminiferous tubules of busulfan-induced azoospermic rats J Hum Reprod Sci 8(2) 103-110 https://doi.org/10.4103/09741208.158618 PMID: 26157302 PMCID: 4477447

42. Mancheño-Corvo $P$, Lopez-Santalla $M$, and Menta R, et al (2017) Intralymphatic administration of adipose mesenchymal stem cells reduces the severity of collagen-induced experimental arthritis Front Immunol 21(8) 462 https://doi.org/10.3389/ fimmu.2017.00462

43. Bacou F, Boubaker el Andalousi R, and Daussin P-A, et al (2004) Transplantation of adipose tissue-derived stromal cells increases mass and functional capacity of damaged skeletal muscle Cell Transplant 13 103-111 https://doi.org/10.3727/000000004773301771 PMID: 15129756 
44. Rodriguez AM, Pisani D, and Dechesne CA, et al (2005) Transplantation of a multipotent cell population from human adipose tissue induces dystrophin expression in inmunocompetent mdx mouse J Exp Med 201(9) 1397-1405 https://doi.org/10.1084/ jem.20042224 PMID: 15867092 PMCID: 2213197

45. Herthel DJ (2001) Enhanced suspensory ligament healing in $\mathbf{1 0 0}$ horses by stem cell and other bone marrow components AAEP Proceedings 47 319-321

46. Litzke LE, Wagner E, and Baumgaertner W, et al (2004) Repair of extensive articular cartilage defects in horses by autologous chondrocyte transplantation Ann Biomed Eng 32 57-69 https://doi.org/10.1023/B:ABME.0000007791.81433.1a PMID: 14964722

47. Smok C, Meruane M, and Rojas M (2014) Implantation of autologous stem cells derived from adipose tissue in rat bone fractures Int J Med Surg Sci 1(2) 105-115

48. Choi EW, Shin IS, and Park SY, et al (2014) Characteristics of mouse adipose tissue-derived stem cells and therapeutic comparisons between syngeneic and allogeneic adipose tissue-derived stem cell transplantation in experimental autoimmune thyroiditis Cell Transplant 23(7) 873-887 https://doi.org/10.3727/096368913X664586

49. Choi EW, Yun TW, and Song JW, et al (2015) Preventive effects of CTLA4lg-overexpressing adipose tissue--derived mesenchymal stromal cells in rheumatoid arthritis Cytotherapy 17(3) 271-282 https://doi.org/10.1016/j.jcyt.2014.10.010

50. Chandra V, G S, and Phadnis S, et al (2009) Generation of pancreatic hormone-expressing islet-like cell aggregates from murine adipose tissue-derived stem cells Stem Cells 27(8) 1941-1953 https://doi.org/10.1002/stem.117 PMID: 19544426

51. Chandra V, Swetha G, and Muthyala S, et al (2016) Islet-like cell aggregates generated from human adipose tissue derived stem cells ameliorate experimental diabetes in mice PLoS One 6(6) e20615 https://doi.org/10.1371/journal.pone.0020615

52. Kochegarov A and Lemanski LF (2016) New trends in heart regeneration: a review J Stem Cells Regen Med 12(2) 61-68

53. Singh A, Singh A, and Sen D (2016) Mesenchymal stem cells in cardiac regeneration: a detailed progress report of the last 6 years (2010-2015) Stem Cell Res Ther 782 https://doi.org/10.1186/s13287-016-0341-0

54. Gaustad KG, Boquest AC, and Anderson BE, et al (2004) Differentiation of human adipose tissue stem cells using extracts of rat cardiomyocytes Biochem Biophys Res Commun 314(2) 420-427 https://doi.org/10.1016/j.bbrc.2003.12.109 PMID: 14733922

55. Hu JJ, Sun C, and Lan L, et al (2010) Therapeutic effect of transplanting beta (2) $\mathrm{m}(-) / T h y 1(+)$ bone marrow-derived hepatocyte stem cells transduced with lentiviral-mediated HGF gene into CCI(4)-injured rats J Gene Med 12(3) 244-254 https://doi. org/10.1002/jgm.1439 PMID: 20143305

56. Zhu XY, Zhang XZ, and Xu L, et al (2009) Transplantation of adipose-derived stem cells overexpressing hHGF into cardiac tissue Biochem Biophys Res Commun 379(4) 1084-1090 https://doi.org/10.1016/j.bbrc.2009.01.019 PMID: 19146824

57. Zhu X, Xu L, and Liu X, et al (2013) Establishment of a lentiviral vector encoding human HGF and the infection of human ADSCs Biomed Res Int 2013724896 https://doi.org/10.1155/2013/724896 PMID: 23484149 PMCID: 3581132

58. Bagno LL, Carvalho D, and Mesquita F, et al (2016) Sustained IGF-1 secretion by adipose-derived stem cells improves infarcted heart function Cell Transplant 25(9) 1609-1622 https://doi.org/10.3727/096368915X690215

59. Yang JJ, Yang X, and Liu ZQ, et al (2012) Transplantation of adipose tissue-derived stem cells overexpressing heme oxygenase-1 improves functions and remodeling of infarcted myocardium in rabbits Tohoku J Exp Med 226(3) 231-241 https://doi. org/10.1620/tjem.226.231 PMID: 22450704 
60. Mérida I (2011) Bioingeniería y su aplicación en la ortodoncia Revista Latinoamericana de Ortodoncia y Odontopediatria Ortodoncia.ws edición electrónica [http://www.ortodoncia.ws]

61. Locke M, Windsor J, and Dunbar PR (2009) Human adipose-derived stem cells: isolation, characterization and applications in surgery ANZ J Surg 79 235-244 https://doi.org/10.1111/j.1445-2197.2009.04852.x PMID: 19432707

62. Zhou D, Cheng H, and Liu J, et al (2017) Establishment of human hair follicle mesenchymal stem cells with overexpressed human hepatocyte growth factor Iran J Basic Med Sci 20(6) 662-675 https://doi.org/10.22038/ijbms.2017.8834 PMID: 28702144 PMCID: $\underline{501929}$

63. Tatullo M, Marrelli M, and Paduano F (2015) The regenerative medicine in oral and maxillofacial surgery: the most important innovations in the clinical application of mesenchymal stem cells Int J Med Sci 12(1) 72-77 https://doi.org/10.7150/ijms.10706 PMID: 25552921 PMCID: $\underline{4278878}$

64. Feisst V, Meidinger S, and Locke MB (2015) From bench to bedside: use of human adipose-derived stem cells Stem Cells and Cloning 8 149-162 http://doi.org/10.2147/sccaa.s64373 PMID: 26586955 PMCID: 4636091 Date accessed: 11/10/2017

65. Sushilkumar R, Shabari S, and Chandra V (2015) Potential of mesenchymal stem cell based application in Cancer Int J Hematol Oncol Stem Cell Res 9(2) 95-103

66. Wei HJ, Zeng R, and Lu JH, et al (2015) Adipose-derived stem cells promote tumor initiation and accelerate tumor growth by interleukin-6 production Oncotarget 6 7713-7726 https://doi.org/10.18632/oncotarget.3481 PMID: 25797257 PMCID: 4480711

67. O'Halloran N, Courtney D, and Kerin MJ, et al (2017) Adipose-derived stem cells in novel approaches to breast reconstruction: their suitability for tissue engineering and oncological safety Breast Cancer (Auckl) 111178223417726777 https://doi. org/10.1177/1178223417726777

68. Shah K (2012) Mesenchymal stem cells engineered for cancer therapy Adv Drug Deliv Rev 64(8) 739-748 https://doi.org/10.1016/j. addr.2011.06.010 PMCID: $\underline{3395998}$

69. Karnoub AE, Dash AB, and Vo AP, et al (2007) Mesenchymal stem cells within tumour stroma promote breast cancer metastasis Nature 449 557-563 https://doi.org/10.1038/nature06188 PMID: 17914389

70. Catalán V, Gómez-Ambrosi J, and Rodríguez A, et al (2013) Adipose tissue immunity and cancer Front Physiol https://doi. org/10.3389/fphys.2013.00275 PMID: 24106481 PMCID: $\underline{3788329}$

71. Desmouliere A, Guyot C, and Gabbiani G (2004) The stroma reaction myofbroblast: a key player in the control of tumor cell behavior Int J Dev Biol 48 509-517 https://doi.org/10.1387/ijdb.041802ad

72. Orimo A and Weinberg RA (2006) Stromal flbroblasts in cancer: a novel tumor-promoting cell type Cell Cycle 5 1597-1601 https://doi.org/10.4161/cc.5.15.3112 PMID: 16880743

73. Safford KM, Hicok KC, and Safford SD, et al (2002) Neurogenic differentiation of murine and human adipose-derived stromal cells Biochem Biophys Res Commun 294 371-379 https://doi.org/10.1016/S0006-291X(02)00469-2 PMID: 12051722

74. Kaewsuwan S, Plubrukarn A, and Utsintong M, et al (2016) Interrupting B induces brown adipocyte differentiation and glucose consumption in adipose-derived stem cells Mol Med Rep 13(3) 2078-2086 https://doi.org/10.3892/mmr.2016.4758 PMID: 26781331 PMCID: 4 P769002

75. Pendleton C, Li Q, and Chesler DA, et al (2013) Mesenchymal stem cells derived from adipose tissue vs bone marrow: in vitro comparison of their tropism towards gliomas PLoS One 8(3) e58198 https://doi.org/10.1371/journal.pone.0058198 PMID: 23554877 PMCID: $\underline{3595264}$ 
ecancer $2018,12: 822$

76. Aivaliotis IL, Pateras IS, and Papaioannou M, et al (2012) How do cytokines trigger genomic instability J Biomed Biotechnol 2012 536761 https://doi.org/10.1155/2012/536761

77. Heo J, Ahn EK, and Jeong HG, et al (2013) Transcriptional characterization of Wnt pathway during sequential hepatic differentiation of human embryonic stem cells and adiposetissue-derived stem cells Biochem Biophys Res Commun 434(2) 235-240 https://doi.org/10.1016/j.bbrc.2013.02.109 PMID: 23541944

78. Lakshmipathy $U$ and Hart RP (2008) Concise review: microRNA expression in multipotent mesenchymal stromal cells Stem Cells 2(26) 356-363 https://doi.org/10.1634/stemcells.2007-0625

79. Keller S, Sanderson MP, and Stoeck A, et al (2006) Exosomes: from biogenesis and secretion to biological function Immunol Lett 107 102-108 https://doi.org/10.1016/j.imlet.2006.09.005 PMID: 17067686

80. Mathivanan S, Ji H, and Simpson RJ (2010) Exosomes: extracellular organelles important in intercellular communication J Proteomics 73(10) 1907-1920 https://doi.org/10.1016/j.jprot.2010.06.006 PMID: 20601276

81. Ataman MG, Uysal CA, and Ertas NM, et al (2016) The effect of adipose stromal vascular fraction on transverse rectus abdominis musculocutaneous, flap: an experimental study J Plast Surg Hand Surg 24 1-9

82. Combellack E, Jessop Z, and Naderi N, et al (2016) Adipose regeneration and implications for breast reconstruction: update and the future Gland Surg 5(2) 227-241 https://doi.org/10.3978/j.issn.2227-684X.2016.01.01 PMID: 27047789 PMCID: 4791352

83. Waked K, Colle J, and Doornaert M, et al (2017) Systematic review: the oncological safety of adipose fat transfer after breast cancer surgery Breast 31 128-136 https://doi.org/10.1016/j.breast.2016.11.001

84. De Decker M, De Schrijver L, and Thiessen F, et al (2016) Breast cancer and fat grafting: efficacy, safety and complications-a systematic review Eur J Obstet Gynecol Reprod Biol 207 100-108 https://doi.org/10.1016/j.ejogrb.2016.10.032 PMID: 27835828

85. Na YK, Ban JJ, and Lee M, et al (2017) Wound healing potential of adipose tissue ítem cell extract Biochem Biophys Res Commun 485(1) 30-34 https://doi.org/10.1016/j.bbrc.2017.01.103 PMID: 28137582

86. Dougherty JA, Mergaye M, and Kumar N, et al (2017) Potential role of exosomes in mending a broken heart: nanoshuttles propelling future clinical therapeutics forward Stem Cells Int 20175785436 https://doi.org/10.1155/2017/5785436 PMID: 29163642 PMCID: $\underline{562033}$

87. Tamama K and Kerpedjieva SS (2012) Acceleration of Wound Healing by Multiple Growth Factors and Cytokines Secreted from Multipotential Stromal Cells/Mesenchymal Stem Cells Adv Wound Care (New Rochelle) 1(4) 177-182 https://doi.org/10.1089/ wound.2011.0296

88. Overman JR, Helder MN, and ten Bruggenkate CM, et al (2013) Growth factor gene expression profiles of bone morphogenetic protein-2-treated human adipose stem cells seeded on calcium phosphate scaffolds in vitro Biochimie 95(12) 2304-2313 https://doi.org/10.1016/j.biochi.2013.08.034 PMID: 24028822

89. Brini AT, Amodeo G, and Ferreira LM, et al (2017) Therapeutic effect of human adipose-derived stem cells and their secretome in experimental diabetic pain Sci Rep 7(1) 9904 https://doi.org/10.1038/s41598-017-09487-5 PMID: 28851944 PMCID: 5575274

90. Vizoso FJ, Eiro N, and Cid S, et al (2017) Mesenchymal stem cell secretome: toward cell-free therapeutic strategies in regenerative medicine Int J Mol Sci 18(9) 1852 https://doi.org/10.3390/ijms18091852 PMCID: $\underline{5618501}$

91. Xia X, Chiu PWY, and Lam PK, et al (2018) Secretome from hypoxia-conditioned adipose-derived mesenchymal stem cells promotes the healing of gastric mucosal injury in a rodent model Biochim Biophys Acta 1864(1) 178-188 https://doi.org/10.1016/j. bbadis.2017.10.009 
92. Chae DS, Han S, and Son M, et al (2017) Stromal vascular fraction shows robust wound healing through high chemotactic and epithelialization property Cytotherapy 19(4) 543-554 https://doi.org/10.1016/j.jcyt.2017.01.006 PMID: 28209525

93. Li Q, Guo Y, and Chen F, et al (2016) Stromal cell-derived factor-1 promotes human adipose tissue-derived stem cell survival and chronic wound healing Exp Ther Med 12(1) 45-50 https://doi.org/10.3892/etm.2016.3309 PMID: 27347016 PMCID: 4906949

94. Li Y, Zhang W, and Gao J, et al (2016) Adipose tissue-derived stem cells suppress hypertrophic scar fibrosis via the p38/MAPK signaling pathway Stem Cell Res Ther 7(1) 102 https://doi.org/10.1186/s13287-016-0356-6 PMID: 27484727 PMCID: 4970202

95. Wang L, Hu L, and Zhou X, et al (2017) Exosomes secreted by human adipose mesenchymal stem cells promote scarless cutaneous repair by regulating extracellular matrix remodelling Sci Rep 7(1) 13321 https://doi.org/10.1038/s41598-017-12919-x PMID: 29042658 PMCID: $\underline{5645460}$

96. Condé-Green A, Marano AA, and Lee ES, et al (2016) Fat grafting and adipose-derived regenerative cells in burn wound healing and scarring: a systematic review of the literature Plast Reconstr Surg 137(1) 302-312 https://doi.org/10.1097/ PRS.0000000000001918

97. Katsuda T, Oki K, Ochiya T (2015) Potential application of extracellular vesicles of human adipose tissue-derived mesenchymal stem cells in Alzheimer's disease therapeutics Methods Mol Biol 1212 171-181 https://doi.org/10.1007/7651_2014 98

98. Shalaby SM, Sabbah NA, and Saber T, et al (2016) Adipose-derived mesenchymal stem cells modulate the immune response in chronic experimental autoimmune encephalomyelitis model IUBMB Life 68(2) 106-115 https://doi.org/10.1002/iub.1469 PMID: $\underline{26757144}$

99. Maria AT, Maumus M, and Le Quellec A, et al (2017) Adipose-derived mesenchymal stem cells in autoimmune disorders: state of the art and perspectives for systemic sclerosis Clin Rev Allergy Immunol 52(2) 234-259 https://doi.org/10.1007/s12016-016$\underline{8552-9}$

100.Bashar AE, Metcalfe AL, and Viringipurampeer IA, et al (2016) An ex vivo gene therapy approach in X-linked retinoschisis Mol Vis 22 718-733 PMID: 27390514 PMCID: 4919093

101. Mangraviti A, Tzeng SY, and Gullotti D, et al (2016) Non-virally engineered human adipose mesenchymal stem cells produce BMP4, target brain tumors, and extend survival Biomaterials 100 53-66 https://doi.org/10.1016/j.biomaterials.2016.05.025 PMID: 27240162 PMCID: $\underline{4902753}$

102. Choi SA, Lee YE, and Kwak PA, et al (2015) Clinically applicable human adipose tissue-derived mesenchymal stem cells delivering therapeutic genes to brainstem gliomas Cancer Gene Ther 22(6) 302-311 https://doi.org/10.1038/cgt.2015.25 PMID: $\underline{26021486}$

103. Huynh NC, Everts V, and Ampornaramveth RS (2017) Histone deacetylases and their roles in mineralized tissue regeneration Bone Rep 16(7) 33-40 https://doi.org/10.1016/j.bonr.2017.08.001

104.Ge W, Liu Y, and Chen T, et al (2014) The epigenetic promotion of osteogenic differentiation of human adipose-derived stem cells by the genetic and chemical blockade of histone demethylase LSD1 Biomaterials 35(23) 6015-6025 https://doi.org/10.1016/j. biomaterials.2014.04.055 PMID: 24794925 